\title{
A modest step forward in New York
}

IN 1969 the United Nations solemnly declared the next ten years a Disarmament Decade. Now, as this period draws to a close, one may reasonably wonder whether it has been anything other than meaningless, with so little progress on so many fronts. Perhaps the only chance that these ten years will be remembered is that the United Nations General Assembly's special session on disarmament, recently ended, will prove to be a turning point. And on that, one can at least say that it didn't end up as a disaster; that a final document of substantial proportions was agreed on; that measures have been taken to keep disarmament nearer the centre of the international stage; and that although nothing spectacular has emerged, there was an air of quiet satisfaction about many of the participants.

It is forty-seven years since the last truly international conference on disarmament, although of course there have been all manner of bilateral and multilateral gatherings. Thus there was a certain amount of trepidation about this giant assembly. Would it degenerate into pious talk, abuse or just airy nothings? In the end these worst fears were not realised. Certainly the final document is overinflated and there are the compulsory remarks about the new international economic order, general and complete disarmament, the armaments of racist regimes and so on. But on the whole there is ample evidence that most participants understood the excruciating complexity of balancing security with disarmament.

If there is one major criticism to be directed at the report it is the obsession with nuclear weapons. They are declared top priority in disarmament negotiations and they are called the greatest danger to mankind and to the survival of civilisation. This perfectly proper unhappiness with the dilatory way in which nuclearweapon states have approached disarmament has distracted just a little too much attention away from conventional arms and the massive trade in them. The strongest remarks the assembly can muster on this latter subject are that "consultations should be carried out among major arms supplier and recipient countries on the limitations of all types of international transfer of conventional weapons . . with a view to promoting or enhancing stability at a lower military level, taking into account the need of all states to protect their security as well as the inalienable right to self-determination and independence of peoples under colonial or foreign domination ....". Such tepidly recommended consultations seem most unlikely ever to come about. Many would have liked to see the UN generate a really major study on the arms trade, but, it is said, India led a group of nations which blocked any such development.

Most of the proposed projects and studies got politely shunted off into an appendix. One that did, however, receive favourable mention was on the relationship between disarmament and development. The SecretaryGeneral of the UN has been charged with convening a study group to prepare a 'forward-looking and policyoriented' report on this issue.

It was widely expected that the present Conference of the Committee on Disarmament which meets in Geneva would not survive intact, and so it has turned out. The present arrangement of 31 countries, under the cochairmanship of the United States and the Soviet Union, has not been entirely satisfactory, particularly because China is excluded and France has chosen not to show up. In the new arrangement the Committee on Disarmament will be up to 40 in number, and the chairmanship will rotate throughout all the members; there is a clear expectation that this will bring France, and eventually China into the fold. The assembly also made a distinction between a gathering to negotiate (which is what the Committee on Disarmament is) and a gathering to deliberate. For the latter purpose a Disarmament Commission of all members of the UN has been set up. This commission will, amongst other things, follow up the decisions and recommendations of the special assembly.

If nothing remarkable has emerged from this special session, perhaps the most tangible advance has been the 'negative security assurances' that nuclear-weapon states have made public. These are undertakings not to use nuclear weapons against non-nuclear states which are not acting in conjunction with a nuclear state. The United States, Soviet Union and United Kingdom have given such assurances; China has given a no-first-use pledge and France has simply declared she will respect nuclear-weapon-free zones.

Delegates left New York promising that the special session would be repeated, perhaps in three years time. By then SALT 2, a test ban and maybe further nuclearfree zones should have been negotiated. The next step must then be to face up to trade in conventional weapons. 